\title{
Karakteristik Kandungan Fukosantin dan Aktivitas Antioksidan Ekstrak Alga Coklat (Sargassum polycystum) pada Perlakuan Konsentrasi Pelarut Aseton dan Suhu Maserasi \\ Characteristics of Fucoxanthin and Antioxidant Activity of Brown Algae Extract (Sargassum polycystum) on Aseton Solvent Concentration and Maceration Temperature
}

\author{
Ni Kadek Eka Wati, Lutfi Suhendra*, Ni Made Wartini \\ PS Teknologi Industri Pertanian, Fakultas Teknologi Pertanian, Universitas Udayana, Kampus Bukit \\ Jimbaran, Badung, Kode pos : 80361; Telp/Fax : (0361) 701801.
}

Diterima 10 September 2019 / Disetujui 08 Nopember 2019

\begin{abstract}
Fucoxanthin has great potential to be developed as an antioxidant. The purposes of this study were to determine the effect of acetone solvent concentration and maceration temperature on the fucoxanthin content and antioxidant activity of brown algae extract (Sargassum polycystum) and determine the best acetone solvent concentration and maceration temperature on the fucoxanthin content and antioxidant activity of brown algae extract (Sargassum polycystum). The study was the experimental research which designed by using randomized block desin (RBD) with two factors. The first factor was solvent concentration that consists of 70, 80 and 90 percent. The second factor was maceration temperature that consists of $30 \pm 2{ }^{\circ} \mathrm{C}, 40 \pm 2^{\circ} \mathrm{C}$ and $50 \pm 2{ }^{\circ} \mathrm{C}$. The data were analyzed by analysis of varian (ANOVA) and continued with the Tukey test. The results showed that the concentration of acetone solvent was influential on the content of fucoxanthin and antioxidant activity but did not affect the yield. Maceration temperature is influential on yield, fucoxanthin content and antioxidant activity. Interactions between treatments of acetone solvent concentration and maceration temperature greatly affect the content of fucoxanthin and antioxidant activity but do not affect the yield. The treatment of acetone 80 percent solvent concentration and maceration temperature $30 \pm 2^{\circ} \mathrm{C}$ is the best treatment to produce brown algae extract (Sargassum polycystum) with a yield of $3.24 \pm 0.45$ percent, fucoxanthin content $1.03 \pm 0.01 \mathrm{~g}$ fukosantin/g and antioxidant activity $99 \pm 8.49 \mathrm{ppm}$ and show activity powerful antioxidant.
\end{abstract}

Keywords: Sargassum polycystum, acetone, maceration, fucoxanthin, antioxidant.

\begin{abstract}
ABSTRAK
Fukosantin memiliki potensi yang besar untuk dikembangkan sebagai antioksidan. Tujuan dari penelitian ini adalah untuk mengetahui pengaruh konsentrasi pelarut aseton dan suhu maserasi terhadap kandungan fukosantin dan aktivitas antioksidan ekstrak alga coklat (Sargassum polycystum) serta menentukan konsentrasi pelarut aseton dan suhu maserasi yang terbaik terhadap kandungan fukosantin dan aktivitas antioksidan ekstrak alga coklat (Sargassum polycystum). Percobaan ini menggunakan Rancangan Acak Kelompok dengan dua faktor. Faktor pertama yaitu perlakuan konsentrasi pelarut yang terdiri dari aseton 70,80 dan 90 persen. Faktor kedua yaitu suhu maserasi yang terdiri dari $30 \pm 2^{\circ} \mathrm{C}$, $40 \pm 2^{\circ} \mathrm{C}$ dan $50 \pm 2^{\circ} \mathrm{C}$. Data dianalisis menggunakan analisis varian dan dilanjutkan dengan uji BNJ. Hasil
\end{abstract}

\footnotetext{
*Korespondensi Penulis:

Email : lutfi_s@unud.ac.id
} 
penelitian menunjukkan bahwa konsentrasi pelarut aseton berpengaruh terhadap kandungan fukosantin dan aktivitas antioksidan tetapi tidak berpengaruh pada rendemen. Suhu maserasi berpengaruh pada rendemen, kandungan fukosantin dan aktivitas antioksidan. Interaksi antar perlakuan konsentrasi pelarut aseton dan suhu maserasi bepengaruh pada kandungan fukosantin dan aktivitas antioksidan tetapi tidak berpengaruh pada rendemen. Perlakuan konsentrasi pelarut aseton 80 persen dan suhu maserasi $30 \pm 2^{\circ} \mathrm{C}$ merupakan perlakuan terbaik untuk menghasilkan ekstrak alga coklat (Sargassum polycystum) dengan rendemen 3,24 $\pm 0,45$ persen, kandungan fukosantin 1,03 $\pm 0,01 \mathrm{~g}$ fukosantin/g dan aktivitas antioksidan $99 \pm 8,49$ ppm dan menunjukkan aktivitas antioksidan kuat

Kata kunci: Sargassum polycystum, aseton, maserasi, fukosantin, antioksidan

\section{PENDAHULUAN}

Rumput laut merupakan komoditi potensial di Indonesia yang terbagi menjadi tiga jenis yaitu rumput laut merah (Rhodophyta), rumput laut hijau (Chlorophyta) dan rumput laut coklat (Phaeophyta) (Maharani et al., 2017). Sargassum polycystum merupakan salah satu rumput laut coklat genus Sargassum yang termasuk dalam kelas Phaeophyceae. Rumput laut coklat jenis Sargassum polycystum tumbuh liar disekitar pantai Tanjung Benoa, Nusa Dua Bali. Saat ini rumput laut coklat yang tumbuh liar di sekitar Pantai Tanjung Benoa belum dimanfaatkan sama sekali sehingga tidak memiliki nilai ekonomis. Produksi rumput laut di Indonesia meningkat cukup signifikan dengan peningkatan mencapai 76,4 persen dari 5,2 juta ton basah rumput laut pada tahun 2011 menjadi 9,2 juta ton pada tahun 2013 . Produksi rumput laut di indonesia didominasi oleh kepulauan Sulawesi dengan kontribusi mencapai 52,3 persen dari total produksi rumput laut basah tahun 2013 mencapai 9,2 ton. Kontribusi kedua berasal dari Nusa Tenggara dan Bali mencapai 28,1 persen dari produksi rumput laut kering basah nasional (KKP, 2014). Rumput laut coklat jenis Sargassum polycystum ini dapat dimanfaatkan sebagai antioksidan. Pigmen yang dominan dari golongan karotenoid dalam biota laut adalah fukosantin yang merupakan golongan santofil. Pigmen ini terutama dihasilkan oleh rumput laut coklat (Phaephyceae) (Terasaki et al., 2009; Peng et al., 2011) sekaligus menjadi faktor utama yang menentukan warna coklat pada rumput laut tersebut. Fukosantin dari alga coklat berpotensi untuk dikembangkan sebagai bahan nutraseutikal terutama sebagai antioksidan dan agen kemopreventif karena kemampuannya dalam meredam radikal bebas (Nursid et al., 2013) Rumput laut Padina sp. dan Sargassum sp. memiliki kandungan fukosantin berturut-turut sebesar $0,6368 \mathrm{mg} / \mathrm{g}$ dan $0,47 \mathrm{mg} / \mathrm{g}$ (Limantara dan Heriyanto, 2010 ; Noviendri et al., 2011 ). Fukosantin merupakan senyawa yang bersifat polar maka diperlukan pelarut yang bersifat polar untuk mendapatkan ekstraknya. Pelarut yang bersifat polar diantaranya adalah etanol, metanol, aseton dan air (Sudarmadji et al., 1997).

Maserasi adalah teknik yang digunakan untuk menarik atau mengambil senyawa yang diinginkan dari suatu larutan atau padatan dengan teknik perendam terhadap bahan yang akan diekstraksi. Sampel yang telah dihaluskan direndam dalam suatu pelarut organik selama beberapa waktu (Ibrahim dan Marham, 2013). Proses ekstraksi dalam penelitian ini menggunakan pelarut aseton. Aseton merupakan pelarut yang banyak digunakan untuk mengekstrak senyawa karotenoid (Rodriguez-Bernaldo de Quiros dan Costa, 2006). Pelarut aseton memiliki polaritas menengah sehingga dapat melarutkan baik senyawa polar maupun non polar termasuk senyawa karotenoid fukosantin yang terdapat pada alga coklat (Sargassum polycystum).

Faktor-faktor yang mempengaruhi 
proses ekstraksi yaitu suhu, waktu ekstraksi, ukuran partikel, jenis pelarut dan konsentrasi pelarut, ukuran partikel, rasio bahan dengan pelarut. Konsentrasi pelarut berdampak pada kepolaritasan pelarut. Konsentrasi pelarut yang berbeda-beda ditujukan untuk mendapatkan pelarut dengan kepolaran mendekati kandungan fukosantin pada alga coklat (Sargassum polycystum). Pada penelitian ekstraksi Sargassum sp. menunjukkan bahwa aseton 80 persen menghasilkan fraksi aktif fukosantin sebesar $0,30 \mathrm{mg} / \mathrm{g}$ (Nasution, 2018). Sudhakar et al. (2013) menunjukkan bahwa rendemen pigmen fukosantin pada pelarut aseton 90 persen yaitu sargassum sp. sebesar 0,23 $\mathrm{mg} / \mathrm{g}$. Selain konsentrasi pelarut, suhu juga dapat mempengaruhi proses ekstraksi. Suhu yang terlalu rendah atau terlalu tinggi sangat berpengaruh terhadap proses ekstraksi. Suhu tinggi dapat mempercepat pelarut untuk berpenetrasi ke dalam bahan dan kontak dengan bahan, tetapi suhu yang terlalu tinggi juga dapat merusak komponen bioaktif bahan (Maleta et al., 2018). Keberadaan sistem ikatan rangkap terkonjugasi pada fukosantin menyebabkan pigmen mudah rusak oleh degradasi oksidatif seperti zat kimia, enzim, suhu, oksigen dan cahaya (Gross, 1991). Senyawa fukosantin tidak stabil pada suhu tinggi. Suhu tinggi dapat dapat merusak kandungan fukosantin sehingga menyebabkan terputusnya ikatan rangkap terkonjugasi sehingga mengakibatkan penurunan aktivitas fukosantin. Menurut Muchtadi (1992) karotenoid memiliki sifat yang cukup tahan terhadap suhu tinggi hingga suhu $60^{\circ} \mathrm{C}$.

Mikroemulsi fukosantin yang dipanaskan selama 5 jam pada suhu $105^{\circ} \mathrm{C}$ mengalami penurunan nilai absorbansi dibandingkan mikroemulsi fukosantin sebelum dipanaskan. Kerusakan fukosantin diduga tidak tahan pemanasan pada suhu tinggi, sehingga pemanasan suhu tinggi menyebabkan fukosantin terdegradasi
(Suhendra et al., 2014). Penelitian Nursid dan Noviendri (2017) menunjukkan bahwa maserasi selama 24 jam pada suhu $30^{\circ} \mathrm{C}$ menghasilkan kandungan fukosantin pada Padina australis sebesar 13,15 mg/10g. Menurut Simanjunak (2008) proses pengekstrakan simplisia dilakukan dengan menggunakan suatu pelarut tertentu, dengan beberapa kali pengocokan atau pengadukan pada temperatur yaitu suhu $40-50^{\circ} \mathrm{C}$.

Berdasarkan hal tersebut perlu dilakukan penelitian mengenai pengaruh konsentrasi pelarut aseton dan suhu maserasi terhadap kandungan fukosantin dan aktivitas antioksidan ekstrak alga coklat (Sargassum polycystum) menggunakan konsentrasi pelarut aseton 70 persen, 80 persen dan 90 persen dengan suhu maserasi $30 \pm 2^{\circ} \mathrm{C}, 40 \pm 2^{\circ} \mathrm{C}$ dan $50 \pm 2^{\circ} \mathrm{C}$. Sehingga diperoleh konsentrasi pelarut aseton dan suhu maserasi terbaik terhadap kandungan fukosantin dan aktivitas antioksidan ekstrak alga coklat (Sargassum polycystum)

\section{METODE PENELITIAN}

\section{Tempat dan Waktu Penelitian}

Penelitian ini dilakukan di Laboratorium Rekayasa Proses dan Pengendalian Mutu, Laboratorium Analisis Pangan serta Laboratorium Pengolahan Pangan Fakultas Teknologi Pertanian Universitas Udayana. Waktu pelaksaan penelitian dimulai dari April sampai Juni 2019.

\section{Bahan dan Alat}

Bahan yang digunakan dalam penelitian ini terdiri dari bahan baku dan bahan kimia. Bahan baku yang digunakan adalah alga coklat jenis Sargassum polycystum dari Pantai Tanjung Benoa, Nusa Dua-Bali. Bahan kimia yang digunakan dalam penelitian ini diantaranya, pelarut untuk ekstraksi yaitu aseton 90 persen (Bratachem). Bahan kimia yang digunakan 
untuk analisis adalah pelarut aseton pa (Merck), metanol pa (Merck) dan larutan 1,1-difenil-2-pikrilhidrazil (DPPH) (aldrich).

Peralatan yang digunakan dalam penelitian ini adalah blender (Philips), shaker (Eyela multi shaker), timbangan analitik (Shimadzu), mikropipet (Socorex), cawan porselin, spektrofotometer UV - Vis (Genesys $5_{s} \quad U$ v-Vis), rotary vakum evaporator (Ika Labortechnik), tabung reaksi (pyrex), pipet volume (pyrex), gelas beker (pyrex), erlenmeyer (pyrex), kertas saring kasar, kertas saring Whatman no 1, alumunium foil, labu ukur (pyrex), ayakan 60 mesh, desikator, spatula dan oven (Memert).

\section{Rancangan Percobaan}

Penelitian ini merupakan percobaan faktorial 2 faktor menggunakan Rancangan Acak Kelompok (RAK). Faktor pertama yaitu konsentrasi pelarut aseton $(\mathrm{P})$ yang terdiri dari 3 taraf yaitu $\mathrm{P} 1$ : 70 persen, $\mathrm{P} 2: 80$ persen, P3: 90 persen. Faktor kedua yaitu suhu maserasi (S) yang terdiri dari 3 taraf yaitu: S1: $30 \pm 2^{\circ} \mathrm{C}, \mathrm{S} 2$ : $40 \pm 2{ }^{\circ} \mathrm{C}, \mathrm{S} 3: 50 \pm 2{ }^{\circ} \mathrm{C}$. Berdasarkan kedua faktor tersebut maka diperoleh 9 perlakuan kombinasi. Masingmasing perlakuan tersebut dikelompokkan menjadi 2 kelompok berdasarkan waktu pelaksanaan sehingga akan diperoleh 18 unit percobaan.

Data yang diperoleh kemudian dianalisis dengan Analysis of Variance (ANOVA) dan apabila perlakuan berpengaruh akan dilanjutkan dengan uji Beda Nyata Jujur (BNJ) menggunakan software minitab 17. Penentuan perlakuan terbaik dilihat berdasarkan nilai tertinggi dari beberapa parameter yang diuji dengan menggunakan uji indeks efektivitas (De Garmo et al., 1984).

\section{Pelaksanaan Penelitian}

\section{Pembuatan Bubuk Sargassum polycystum}

Pembuatan bubuk Sargassum polycystum dilakukan menurut Maulina et al.
(2018). Rumput laut Sargassum polycystum segar kemudian dicuci bersih untuk menghilangkan sisa kotoran dan benda asing yang menempel. Rumput laut Sargassum polycystum ditiriskan kemudian dipotong dikeringkan dengan oven pada suhu $45 \pm 2^{\circ} \mathrm{C}$ sampai kering dan mudah dipatahkan dan disimpan dalam ruangan tanpa terpapar cahaya (Maulina et al., 2018). Rumput laut Sargassum polycystum yang telah kering selanjutnya dihancurkan dan diayak menggunakan ayakan 60 mesh, sehingga dihasilkan bubuk rumput laut.

\section{Pembuatan Ekstrak Sargassum polycystum}

Pembuatan ekstrak Sargassum polycystum dilakukan menurut Savitri et al. (2017) yang dimodifikasi. Proses maserasi diawali dengan menimbang $50 \mathrm{~g}$ bubuk rumput laut dimasukkan ke dalam labu erlenmeyer lalu ditambahkan pelarut aseton dengan konsentrasi sesuai perlakuan yaitu (70 persen, 80 persen dan 90 persen) sebanyak $250 \mathrm{ml}$ dengan perbandingan bahan dengan pelarut 1:5 (b/v). Selanjutnya dimaserasi selama 24 jam pada suhu sesuai perlakuan $\left(30 \pm 2{ }^{\circ} \mathrm{C}, 40 \pm 2 \quad{ }^{\circ} \mathrm{C}, 50 \pm 2 \quad{ }^{\circ} \mathrm{C}\right)$. Selama maserasi campuran tersebut diaduk manual setiap 6 jam selama 5 menit.

Ekstrak bercampur pelarut disaring menggunakan kertas saring kasar dan ditampung (filtrat I), sedangkan ampas ditambahkan pelarut aseton dengan konsentrasi sesuai perlakuan sebanyak $50 \mathrm{~mL}$ dan digojog, kemudian disaring dengan kertas saring kasar (filtrat II). Filtrat I dan II dicampur sehingga didapatkan ekstrak Sargassum polycystum yang masih tercampur dengan pelarut dan selanjutnya disaring dengan kertas Whatman No. 1. Selanjutnya filtrat dievaporasi dengan rotary evaporator pada suhu $40^{\circ} \mathrm{C}$ dengan tekanan $100 \mathrm{mBar}$ untuk menghilangkan pelarut yang terdapat dalam ekstrak sehingga dihasilkan ekstrak kental. Evaporasi dihentikan apabila pelarut tidak menetes lagi dalam jangka waktu 5 
menit. Ekstrak Sargassum polycystum kental yang diperoleh dimasukkan ke dalam botol sampel dan dianalisis.

\section{Parameter yang Diamati}

Parameter yang diamati pada penelitian ini adalah rendemen ekstrak (Sudarmadji et al., 1989), kandungan fukosantin (Kartini dan Kartikaningsih, 2014), aktivitas antioksidan (Prayoga, 2013 yang dimodifikasi). Penentuan perlakuan terbaik dilihat berdasarkan nilai tertinggi dari beberapa parameter yang diuji dengan menggunakan uji indeks efektivitas (De
Garmo et al., 1984).

\section{HASIL DAN PEMBAHASAN}

\section{Rendemen Ekstrak Alga Coklat}

Hasil analisis ragam menunjukkan bahwa perlakuan konsentrasi pelarut aseton berpengaruh tidak nyata $(\mathrm{P}>0,05)$ dan suhu maserasi berpengaruh sangat nyata $(\mathrm{P}<0,01)$ dan interaksi antar perlakuan berpengaruh tidak nyata $(\mathrm{P}>0,05)$ terhadap rendemen ekstrak alga coklat $(S$. polycystum). Nilai rata-rata rendemen ekstrak alga coklat $(S$. polycystum) dapat dilihat pada Tabel 1.

Tabel 2. Nilai rata-rata rendemen (\%) ekstrak alga coklat (S. polycystum)

\begin{tabular}{ccccc}
\hline Konsentrasi Pelarut & \multicolumn{3}{c}{ Suhu Maserasi $\left({ }^{\circ} \mathrm{C}\right)$} & \multirow{2}{*}{ Rata-rata } \\
\cline { 2 - 4 } Aseton (\%) & 30 & 40 & 50 & \\
\hline 70 & $2,44 \pm 0,37$ & $3,03 \pm 0,01$ & $3,65 \pm 0,27$ & $3,04 \pm 0,58 \mathrm{a}$ \\
80 & $2,41 \pm 0,28$ & $3,09 \pm 0,14$ & $3,92 \pm 0,02$ & $3,13 \pm 0,69 \mathrm{a}$ \\
90 & $2,83 \pm 0,16$ & $3,11 \pm 0,06$ & $3,77 \pm 0,17$ & $3,24 \pm 0,45 \mathrm{a}$ \\
\hline Rata-rata & $2,55 \pm 0,30 \mathrm{c}$ & $3,08 \pm 0,08 \mathrm{~b}$ & $3,78 \pm 0,19 \mathrm{a}$ & \\
\hline
\end{tabular}

Keterangan: Huruf yang berbeda di belakang nilai rata-rata pada baris dan kolom yang sama menunjukkan perbedaan yang nyata $(\mathrm{P}>0,05)$.

Tabel 2 menunjukkan bahwa pada konsentrasi pelarut aseton 90 persen menghasilkan rendemen ekstrak alga coklat $(S$. polycystum ) lebih tinggi sebesar $3,24 \pm 0,45$ persen namun tidak berbeda nyata dengan perlakuan konsentrasi pelarut aseton 70 dan 80 persen. Hal ini disebabkan oleh senyawa kimia yang terdapat pada alga coklat (S. polycystum) meningkat kelarutannya pada konsentrasi pelarut aseton 90 persen dimana, semakin tinggi penggunaan konsentrasi pelarut aseton maka semakin banyak rendemen ekstrak yang dihasilkan. Semakin tinggi konsentrasi pelarut maka tingkat kepolarannya semakin berkurang. Konsentrasi pelarut aseton 90 persen memiliki tingkat kepolaran yang rendah karena mengandung sedikit air. Hasil menunjukkan bahwa terdapat beberapa senyawa yang bukan fukosantin ikut terekstrak yang memiliki kepolaran cenderung mendekati kepolaran konsentrasi pelarut aseton 90 persen. Penggunaan konsentrasi pelarut aseton yang berbeda menyebabkan konstanta dielektriknya yang berbeda. Nilai konstanta dielektrik dari masing-masing konsentrasi pelarut aseton 70, 80 dan 90 persen berturut-turut sebesar 38,61; 32,64 dan 26,67. Hasil penelitian ini didukung oleh Fernandes (2018) menunjukkan bahwa dengan konsentrasi pelarut aseton 90 persen menggunakan metode maserasi menghasilkan rendemen Sargassum polycystum sebesar 13,00 $\pm 0,32$ persen. Harbone (1973) menyatakan bahwa prinsip dasar ekstraksi ialah like dissolves like dimana kelarutan suatu senyawa pada pelarut didasari dari kesamaan polaritas antara pelarut dengan senyawa yang diekstrak.

Tabel 2 menunjukkan bahwa suhu maserasi $50 \pm 2^{\circ} \mathrm{C}$ menghasilkan rendemen ekstrak alga coklat (Sargassum polycystum) tertinggi sebesar 3,78 $\pm 0,19$ persen, sedangkan yang terendah dihasilkan oleh 
suhu maserasi $30 \pm 2^{\circ} \mathrm{C}$ sebesar $2,55 \pm 0,30$ persen. Suhu ekstraksi yang semakin tinggi akan menyebabkan gerakan partikel menjadi semakin cepat sehingga kontak antara pelarut dan bahan menjadi lebih efektif (Harjanti, 2008). Hal tersebut menyebabkan pelarut akan mudah melarutkan senyawa pada suhu tinggi, sehingga semakin tinggi suhu maserasi yang digunakan maka semakin banyak senyawa yang dapat terlarut. Menurut Budiyanto dan Yulianingsih (2008) suhu ekstraksi yang tinggi menyebabkan peningkatan energi kinetik larutan sehingga difusi pelarut ke dalam sel semakin meningkat.

\section{Kandungan Fukosantin}

Hasil analisis ragam menunjukkan bahwa perlakuan konsentrasi pelarut aseton, suhu maserasi dan interaksi antar perlakuan berpengaruh sangat nyata $(\mathrm{P}<0,01)$ terhadap kandungan fukosantin ekstrak alga coklat (Sargassum polycystum). Nilai rata-rata kandungan fukosantin ekstrak alga coklat (Sargassum polycystum) dapat dilihat pada Tabel 3.

Tabel 3. Nilai rata-rata kandungan fukosantin (g fukosantin/g) ekstrak alga coklat (Sargassum polycystum)

\begin{tabular}{cccc}
\hline Konsentrasi Pelarut & \multicolumn{3}{c}{ Suhu Maserasi $\left({ }^{\circ} \mathrm{C}\right)$} \\
\cline { 2 - 4 } Aseton $(\%)$ & $30 \pm 2$ & $40 \pm 2$ & $50 \pm 2$ \\
\hline 70 & $0,89 \pm 0,01 \mathrm{bc}$ & $0,74 \pm 0,02 \mathrm{~d}$ & $0,66 \pm 0,01 \mathrm{ef}$ \\
80 & $1,03 \pm 0,01 \mathrm{a}$ & $0,93 \pm 0,01 \mathrm{~b}$ & $0,83 \pm 0,02 \mathrm{c}$ \\
90 & $0,71 \pm 0,01 \mathrm{de}$ & $0,63 \pm 0,01 \mathrm{fg}$ & $0,59 \pm 0,01 \mathrm{~g}$ \\
\hline
\end{tabular}

Keterangan: Huruf yang berbeda di belakang nilai rata-rata menunjukkan perbedaan yang nyata $(\mathrm{P}<0,05)$.

Tabel 3 menunjukkan bahwa perlakuan konsentrasi pelarut aseton dan suhu maserasi yang menghasilkan kandungan fukosantin tertinggi pada perlakuan konsentrasi pelarut aseton 80 persen dan suhu maserasi $30 \pm 2^{\circ} \mathrm{C}$ sebesar $1,03 \pm 0,01 \mathrm{~g}$ fukosantin/g, sedangkan yang terendah dihasilkan oleh konsentrasi pelarut aseton 90 persen dengan suhu maserasi $50 \pm 2^{\circ} \mathrm{C}$ sebesar $0,59 \pm 0,01 \mathrm{~g}$ fukosantin/g. Konsentrasi pelarut aseton dan suhu maserasi akan mempengaruhi kandungan fukosantin dari ekstrak alga coklat. Kandungan fukosantin cenderung menurun pada konsentrasi pelarut aseton dan suhu maserasi yang semakin tinggi. Hal ini disebabkan adanya perbedaan tingkat kepolaran pelarut untuk melarutkan kandungan fukosantin yang terdapat pada ekstrak alga coklat. Konsentrasi pelarut yang lebih tinggi menandakan bahwa jumlah air dalam pelarut semakin sedikit sehingga menyebabkan kepolaritasan pelarut menjadi menurun. Kepolaran fukosantin yang terkandung pada ekstrak alga coklat $(S$. polycystum) mendekati kepolaran konsentrasi pelarut aseton 80 persen. Hal ini didukung oleh penelitian Nasution (2018) mengenai karakteristik fraksi aktif biopigmen fukosantin rumput laut coklat sebagai antioksidan dan uv protector yang menunjukkan bahwa konsentrasi pelarut aseton 80 persen lebih efektif dalam mengekstrak pigmen fukosantin dibandingkan dengan konsentrasi pelarut aseton 90 persen. Hasil ini berbeda dengan hasil rendemen ekstrak diduga disebabkan oleh senyawa yang bukan fukosantin pada alga coklat (S. polycystum) yang lebih banyak terekstrak dibandingkan fukosantin.

Penggunaan suhu maserasi yang terlalu rendah akan menyebabkan kurang maksimalnya pelarut dalam mengekstrak senyawa aktif pada bahan. Apabila menggunakan suhu maserasi yang tinggi hingga batas tertentu selama proses ekstraksi dapat merusak kandungan fukosantin pada 
bahan. Hal ini disebabkan fukosantin memiliki ikatan rangkap terkonjugasi pada struktur fukosantin. Keberadaan sistem ikatan rangkap terkonjugasi menyebabkan pigmen mudah rusak oleh degradasi oksidatif seperti zat kimia, enzim, suhu, oksigen dan cahaya (Gross, 1991). Fukosantin mudah mengalami kerusakan akibat adanya panas dan reaksi oksidasi yang mengakibatkan reaksi pemutusan ikatan rangkap terkonjugasi pada struktur fukosantin yang menyebabkan penurunan aktivitas fukosantin. Menurut Maleta et al. (2018) suhu tinggi dapat mempercepat pelarut untuk berpenetrasi ke dalam bahan dan kontak dengan bahan, tetapi suhu yang terlalu tinggi juga dapat merusak komponen bioaktif bahan.
Aktivitas Antioksidan (IC50)
Hasil analisis ragam menunjukkan bahwa perlakuan konsentrasi pelarut aseton, suhu maserasi dan interaksi antar perlakuan berpengaruh sangat nyata $(\mathrm{P}<0,01)$ terhadap aktivitas antioksidan ekstrak alga coklat $(S$. polycystum). Nilai rata-rata aktivitas antioksidan $\mathrm{IC}_{50}$ ekstrak alga coklat $(S$. polycystum) dapat dilihat pada Tabel 4.

Tabel 4. Nilai rata-rata aktivitas antioksidan $\mathrm{IC}_{50}(\mathrm{ppm})$ ekstrak alga coklat (S. polycystum)

\begin{tabular}{cccc}
\hline Konsentrasi Pelarut & \multicolumn{3}{c}{ Suhu Maserasi $\left({ }^{\circ} \mathrm{C}\right)$} \\
\cline { 2 - 4 } Aseton $(\%)$ & $30 \pm 2$ & $40 \pm 2$ & $50 \pm 2$ \\
\hline 70 & $160 \pm 14,1 \mathrm{de}$ & $170 \pm 11,31 \mathrm{~cd}$ & $234 \pm 24,0 \mathrm{~b}$ \\
80 & $99 \pm 8,49 \mathrm{f}$ & $122 \pm 29,7 \mathrm{ef}$ & $256,5 \pm 20,5 \mathrm{ab}$ \\
90 & $215,50 \pm 16,3 \mathrm{bc}$ & $236,5 \pm 12,02 \mathrm{~b}$ & $284,5 \pm 10,61 \mathrm{a}$ \\
\hline
\end{tabular}

Keterangan: Huruf yang berbeda di belakang nilai rata-rata menunjukkan perbedaan yang nyata $(\mathrm{P}<0,05)$.

Aktivitas antioksidan ekstrak alga coklat (S. polycystum) dapat dilihat dari nilai $\mathrm{IC}_{50}$. $\mathrm{IC}_{50}$ merupakan konsentrasi larutan substrat atau sampel yang akan menyebabkan reduksi terhadap aktivitas DPPH sebesar 50 persen (Molyneuk, 2004). Menurut Wijayanti et al. (2006) semakin rendah nilai $\mathrm{IC}_{50}$ semakin aktif zat tersebut sebagai zat antioksidan.

Tabel 4 menunjukkan bahwa nilai aktivitas antioksidan terendah diperoleh dari ekstrak alga coklat (S. polycystum) perlakuan konsentrasi pelarut aseton 80 persen dan suhu maserasi $30 \pm 2^{\circ} \mathrm{C}$ sebesar $99 \pm 8,49$ ppm dan menunjukkan aktivitas antoksidan kuat, sedangkan nilai $\mathrm{IC}_{50}$ tertinggi diperoleh dari ekstrak alga coklat (S. polycystum) perlakuan konsentrasi pelarut aseton 90 persen dan suhu maserasi $50 \pm 2^{\circ} \mathrm{C}$ sebesar $284,5 \pm 10,61 \mathrm{ppm}$. Aktivitas antioksidan cenderung menurun pada konsentrasi pelarut aseton dan suhu maserasi yang semakin tinggi. Hal ini diakibatkan oleh kepolaran konsentrasi pelarut aseton 80 persen mendekati kepolaran kandungan fukosantin dari ekstrak alga coklat. Aktivitas antioksidan dipengaruhi oleh kandungan fukosantin, sehingga semakin tinggi kandungan fukosantin maka semakin tinggi aktivitas antioksidannya karena fukosantin memiliki peranan dalam menangkal radikal bebas DPPH. Penelitian Nursid et al. (2013) menunjukkan bahwa alga coklat jenis $P$. australis dengan nilai hmbatan terhadap radikal bebas DPPH sebesat 53 persen $\mu \mathrm{g} / \mathrm{ml}$ sehingga hasil penelitian menunjukkan bahwa terdapat korelasi yang nyata antara kandungan fukosantin dengan aktivitas antioksidan.

Suhu maserasi yang semakin tinggi menyebabkan penurunan aktivitas antioksidan yang didapatkan. Hal ini terjadi karena suhu maserasi yang semakin tinggi menyebabkan kandungan fukosantin yang berfungsi sebagai penangkal radikal bebas tidak tahan terhadap panas sehingga apabila diesktrak dengan suhu tinggi maka kandungan fukosantin pada bahan akan menurun. Khatun et al. (2006) 
mengemukakan bahwa penurunan aktivitas antiksidan disebabkan karena terjadi kerusakan komponen aktif, sehingga menimbulkan koagulasi dan menurunkan aktivitas penangkapan radikal bebas. Cheng et al. (2006) menyatakan bahwa panas yang tinggi dapat mengakibatkan perubahan senyawa antioksidan menjadi bentuk lain yang bersifat pada penurunan aktivitas antioksidan pada gandum.

\section{Uji Indeks Efektivitas}

Uji indeks efektivitas bertujuan untuk mengetahui perlakuan terbaik dalam menghasilkan ekstrak alga coklat $(S$. polycystum). Hasil perhitungan uji indeks efektivitas dapat dilihat pada Tabel 5.

Tabel 5. Hasil uji indeks efektivitas ekstrak alga coklat (S. polycystum)

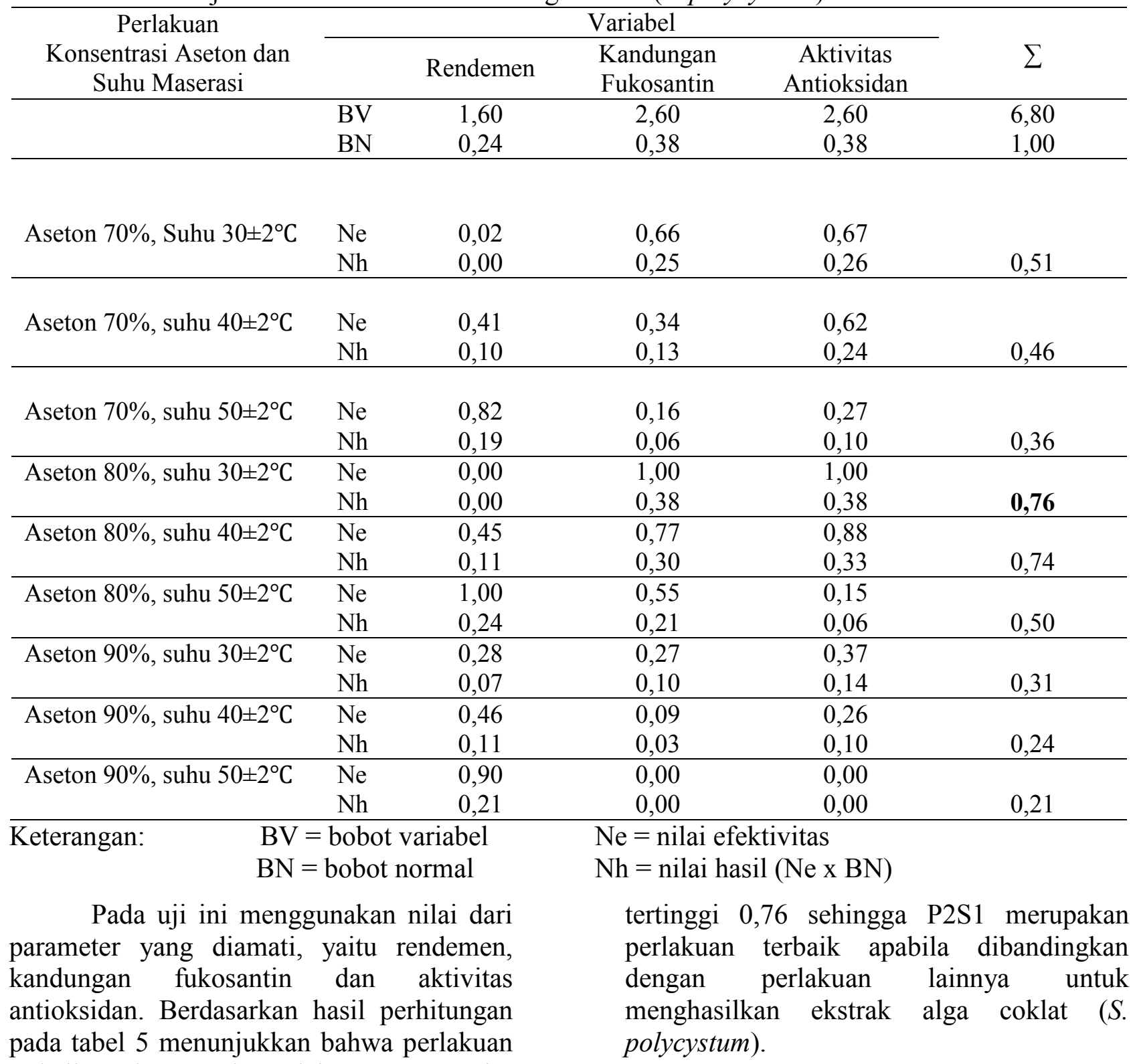
terbaik terdapat pada perlakuan P2S1, yaitu konsentrasi pelarut aseton 80 persen dan suhu KESIMPULAN DAN SARAN maserasi $30 \pm 2^{\circ} \mathrm{C}$ yang memiliki nilai 


\section{Kesimpulan}

Berdasarkan penelitian ini dapat disimpulkan sebagai berikut :

1. Konsentrasi pelarut aseton berpengaruh terhadap kandungan fukosantin dan aktivitas antioksidan tetapi tidak berpengaruh pada rendemen. Suhu maserasi berpengaruh pada rendemen, kandungan fukosantin dan aktivitas antioksidan. Interaksi antar perlakuan konsentrasi pelarut aseton dan suhu maserasi bepengaruh pada aktivitas antioksidan dan kandungan fukosantin tetapi tidak berpengaruh pada rendemen.

2. Kombinasi perlakuan konsentrasi pelarut aseton 80 persen dan suhu maserasi $30 \pm 2^{\circ} \mathrm{C}$ merupakan perlakuan terbaik untuk menghasilkan ekstrak alga coklat (Sargassum polycystum) dengan rendemen 3,24 $\pm 0,45$ persen, kandungan fukosantin 1,03 $\pm 0,01 \mathrm{~g}$ fukosantin/g dan aktivitas antioksidan $99 \pm 8,49 \mathrm{ppm}$ dan menunjukkan aktivitas antioksidan kuat.

\section{Saran}

Berdasarkan hasil penelitian ini dapat disarankan beberapa hal sebagai berikut :

1. Berdasarkan hasil penelitian, untuk menghasilkan kandungan fukosantn dan aktivitas antioksidan ekstrak alga coklat (Sargassum polycystum) yang terbaik disarankan untuk menggunakan konsentrasi pelarut aseton 80 persen dan suhu maserasi $30 \pm 2^{\circ} \mathrm{C}$.

2. Perlu dilakukan penelitian lebih lanjut mengenai stabilitas kandungan fukosantin ekstrak alga coklat (Sargassum polycystum) selama penyimpanan.

\section{DAFTAR PUSTAKA}

Budiyanto, A dan Yulianingsih. 2008. Pengaruh suhu dan waktu ekstraksi terhadap karakter pektin dari ampas jeruk siam (Citrus nobilis L.). Jurnal
Pasca Panen 5(2): 37-44.

Cheng, Z., L. Su, J. Moore, K. Zhou, M. Luther, J.J Yin, and L.L. Yu. 2006. Efeect of posharvest treatment and heat stress on availability of wheat antioxidants. Journal Agricultural Food Chemistry 54(15): 5623-5629.

E.P., W.G. Sullivan and J.R. Canada. 1984. Engineering Economy. 7th Edition. Mac. Millan Publ Co, New York.

Fernandes T. 2018. Karakteristik dan Identifikasi Senyawa Aktif Ekstrak Pigmen Sargassum polycystum dan Padina minor. Skripsi. Tidak dipublikasikan. Fakultas Perikanan dan Ilmu Kelautan. IPB, Bogor.

Gross J. 1991. Pigments in Vegetable, Chlorophylls and Carotenoids. Van Nostrand Reinhold, New York.

Harborne, J.B. 1987. Metode Fitokimia. Penerjemah K. Padmawinata dan I. Soediro. Institut Teknologi Bandung, Bandung.

Ibrahim, S. Dan Marham, S., 2013. Teknik Laboratorium Kimia Organik. Graha Ilmu Yogyakarta.

Jaswir, I., Noviendi, D., Salleh, H.M., Taher, M., and Miyashita. 2011. Isolation of fucoxanthin and fatty acids analysis of Padina australis and cytotoxic effect of fucoxanthin on human lung cancer (H1299) cell lines. African Journal of Biotechnology. 10(81): 18855-18862.

Kartini, Z. dan H. Kartikaningsih. 2014. Studi identifikasi crude fukosantin da fukosantin hasil isolasi dari alga coklat (Padina australis) dengan pengujian spektroskopi FTIR. Jurnal Sains Technology 3(3): 140-143.

Khatun, M., S. Egucgi, T. Yamaguchi, H. Takamura and T. Matoba. 2006. Effect thermal treatment of radical scavening 
activity of some species. Journal Food Science Thecnology Research 12(3): 178-322

KKP. Kelautan dan perikanan dalam angka tahun 2014. Pusat Data Statistik dan Informasi Kementrian Kelautan dan Perikanan.

Limantara, L dan Heriyanto. 2010. Studi komposisi pigmen dan kandungan fukosantin rumput laut coklat dari perairan madura dengan kromatografi cair kinerja tinggi. Jurnal Ilmu Kelautan 15(1): 23-32.

Maharani, A.A. 2017. Pengaruh Metode Ekstraksi Terhadap Karakteristik Natrium Alginat Rumput Laut Sargassum fluitans. Skripsi. Tidak dipublikasikan. Fakultas Pertanian. UGM, Yogyakarta.

Maleta, H.S., R. Indrawati, L. Limantara, dan T.H.P Brotosudarmo. 2018. Ragam metode ekstraksi karotenoid dari sumber tumbuhan dalam dekade terakhir (Telaah Literatur). Jurnal Rekayasa Kimia dan Lingkungan. 13(1): 40-50.

Maulina, S., L. Suhendra, dan I.B.W. Gunam. 2018. Karakteristik bubuk alga coklat (Sargassum polycystum) pada perlakuan ukuran dan suhu pengeringan. Jurnal Rekayasa dan Manajemen Agroindustri 6(1): 1-10.

Molyneux P. 2004. The use of stable free radical diphenylpicylhydrazyl (DPPH) for estimating antioxidant activity. Journal of Science Technology. 26(2): 211-219.

Nasution A.I.S. 2018. Karakteristik fraksi aktif biopigmen fukosantin rumput laut cokelat sebagai antioksidan dan uv protector. Skripsi. Tidak dipublikasikan. Fakultas Perikanan dan Ilmu Kelautan. IPB, Bogor.
Nursid, M., T. Wikanta, dan R. Susulowati. 2013. Aktivitas antioksidan, sitotoksisitas dan kandungan fukosantin ekstrak rumput laut cokelat dari pantai binuangeun, banten. Jurnal Ilmu Kelautan 8(1): 73-84.

Nursid, M., S.A.D, Tantri., dan L. Rahayu. 2015. Sitotoksisitas ekstrak aseton dan kandungan fukosantin rumput laut Sargassum. Jurnal Pengolahan Produk dan Bioteknologi Kelautan dan Perikanan 10(2): 91-99.

Nursid, M., dan D. Noviendri. 2017. Kandungan fukosantin dan fenolik total pada rumput laut cokelat Padina australis yang dikeringkan dengan sinar matahari. Jurnal Pengolahan Produk dan Bioteknologi Kelautan dan Perikanan 12(2): 117-124.

Noviendri, D., I. Jaswir, H.M. Salleh, M. Taher, K. Miyashita and K. Ramli. 2011. Fucoxanthin extraction and fatty acid analysis of Sargassum binder and S. duplicatum. Journal of Medical Plants Research 5(11): 2405-2412.

Peng, J., J.P. Yuan, C.F. Wu, and J.H. Wang. 2011. Fucoxanthin, a marine carotenoid present in brown seaweeds and diatoms: metabolism and bioactivities relevant to human healt. Marine Drugs. 9(10): 1806-1828.

Prayoga, G. 2013. Fraksinasi, uji aktivitas antioksidan dengan metode DPPH dan identifikasi golongan senyawa kimia dari ekstrak teraktif daun sambaing darah (Excoecaria cochinchinensis Lour). Skripsi. Tidak dipublikasikan. Fakultas Farmasi. UI, Depok.

Rodríguez-Bernaldo de Quirós, A., \& Costa, H.S. (2006). Analysis of carotenoids in vegetable and plasma samples: A review. Journal of Food Composition and Analysis, 19, 97-111. 
Savitri, I. L.Suhendra., dan N.M. Wartini. 2017. Pengaruh jenis pelarut pada metode maserasi terhadap karakteristik ekstraks Sargassum polycystum. Jurnal Rekayasa Dan Manajemen Agroindustri 5(3): 93-101.

Simanjuntak, R. M. 2008. Ekstraksi Fraksinasi Komponen Ekstrak Daun Tumbuhan Senduduk (Melastommalabathricum. L) Serta Pengujuan Efek Sediaan Krim Terhadap Penyembuhan Luka Bakar. Skripsi. Tidak dipublikasikan. Fakultas Farmasi. Universitas Sumatera Utara.

Sudarmadji S., B. Haryono dan Suhardi. 1989. Analisis untuk Bahan Makanan dan Pertanian, Yogyakarta.

Sudarmadji S., B. Haryono dan Suhardi. 1997. Prosedur Analisis untuk Bahan Makanan dan Pertanian. Liberty, Yogyakarta.

Suhendra, L., S.Raharjo, P. Hastuti, dan C. Hidayat. 2014. Stabilitas mikroemulsi fucoxanthin dan efektivitasnya dalam menghambat foto oksida vitamin $\mathrm{C}$ pada moden minuman. Jurnal Agritech. 34(2):138:145.

Sudhakar, M.P., Ananthalakshmi, J.S. \& Nair, B.B. 2013. Extraction, purification and study on Antioxidant Properties of Fucoxanthin from Brown Seaweeds. J. Chem. Pharm. Res. 5(7):169-75.
Terasakti, M., A.Hirose, B. Narayan, Y. Baba, C. Kawagoe, H. Yasui and K. Miyashita. 2009. Evaluation of recoverbal functional lipid components of several brown seaweeds (Phaeophyta) from Japan with special reference to fucoxanthin and fucosterol contents. Journal of Phycology 45(4): 974-980.

Widyartini, D.S., A.I. Insan dan Sulistyani. 2012. Meningkatkan pertumbuhan dan produksi rumput laut gracilaria gigas dengan modifikasi metode budidaya dan sistem jaring. Jurnal Penelitian Saintek 9(1): 63-75.

Wijayanti, WA. Dan Z. Yulfi. 2006. Minyak Atsiri Dari Kulit Batang Cinnamomum butmanni (Kayu Manis) Sebagai Inteksida Alam, Antibakteri dan Antioksida. Tugas Akhir. Tidak dipublikasikan. Fakultas Matematika dan Ilmu Pengetahuan Alam Institut Teknologi Sepuluh November, Surabaya. 